\title{
QUANTIFICATION OF BIOFILM PRODUCTION ON POLYSTYRENE BY LISTERIA, ESCHERICHIA COLI AND STAPHYLOCOCCUS AUREUS ISOLATED FROM A POULTRY SLAUGHTERHOUSE
}

\section{Laura Beatriz Rodrigues ${ }^{1,2 *}$; Luciana Ruschel dos Santos ${ }^{1}$; Vinícius Zancanaro Tagliari ${ }^{1}$; Natalie Nadin Rizzo ${ }^{1}$; Graciela Trenhago $^{1}$; Amauri Picollo de Oliveira ${ }^{1}$; Franciane Goetz ${ }^{1}$; Vladimir Pinheiro do Nascimento ${ }^{2}$}

\author{
${ }^{1}$ Faculdade de Agronomia e Medicina Veterinária, Universidade de Passo Fundo, Passo Fundo, RS. Brasil; ${ }^{2}$ Faculdade de \\ Veterinária, Universidade Federal do Rio Grande do Sul, Porto Alegre, RS. Brasil.
}

Submitted: April 11, 2009; Approved: June 21, 2010.

\begin{abstract}
This study assessed biofilm formation on polystyrene by Staphylococcus aureus, Listeria monocytogenes, L. welshimeri and Escherichia coli, isolated from a slaughtering plant, grown on tryptic soy broth (TSB) using different glucose concentrations. The tested bacteria produced biofilm in at least one of the concentrations used, and some of them were strong biofilm producers.
\end{abstract}

Key words: Listeria, Escherichia coli, Staphylococcus aureus, biofilm, polystyrene

\section{INTRODUCTION}

A biofilm is a population of microbial cells growing on a surface and enclosed in an amorphous extracellular matrix. Biofilm formed in food processing environments is of special importance as it has the potential to act as a chronic source of microbial contamination that may lead to food spoilage or transmission of diseases, and bacteria in biofilms exhibit enhanced resistance to cleaning and sanitation (12).

Formation and presence of biofilm have been investigated by different quantification methods, among which the microtiter plate system is widely used $(1,12,14)$. Microtiter plate systems for quantifying biofilm formation have been investigated using many different organisms and stains (1, 2, 13).

Therefore, this study assessed biofilm formation on polystyrene plates by Staphylococcus aureus, Escherichia coli, Listeria monocytogenes and L. welshimeri isolated from the cutting room of a slaughtering plant and grown on tryptic soy broth (TSB) using different glucose concentrations.

This study was conducted in the cutting room of a poultry slaughterhouse in southern Brazil with capacity for 20,000 animals per hour. Samples were collected at the end of the cutting phase, during preoperational cleaning: before the surfaces were washed; after washing with hot water and after washing with $2 \%$ sodium hydroxide detergent (Power Foam ${ }^{\circledR}$, Johnson Diversey), rinsing and disinfection with $0.5 \%$ peracetic acid (Divosan Forte ${ }^{\circledR}$, Johnson Diversey), 2\% quaternary ammonium (Divosan Divoquat Forte ${ }^{\circledR}$, Johnson Diversey), and $1 \%$ biguanide (Divosan Divosept $350^{\circledR}$, Johnson Diversey). The following methods were used: Evancho et al. (3), Hitchins (6), and Ryser and Donnelly (11) for investigation of Listeria sp; Evancho et al. (3) and Lancette and Bennett (8) for counting Staphylococcus aureus, and Evancho et al. (3), Swanson et al. (15) and Kornacki and Johnson (7) for Escherichia coli.

\footnotetext{
*Corresponding Author. Mailing address: Faculdade de Agronomia e Medicina Veterinária, Universidade de Passo Fundo, Faculdade de Veterinária, Universidade Federal do Rio Grande do Sul, RS, Brasil.; E-mail: laurab@upf.br
} 
The method for assessment of biofilm formation on polystyrene microtiter plates was based on the techniques described by Stepanovic et al. $(13,14)$, adapted for the analysis of Listeria sp (6 strains), Escherichia coli (9 strains) and Staphylococcus aureus (11 strains). The standard strains used were Listeria monocytogenes ATCC 7644, Escherichia coli ATCC 25922 and Staphylococcus aureus ATCC 25923. The strains were grown on tryptic soy agar (TSA) without dextrose (Difco) using $1.5 \%$ of agar, without glucose $(0 \%)$, and on TSA supplemented with $0.5 ; 1 ; 1.5 ; 2 ; 2.5 ; 3 ; 3.5$ and $4 \%$ of glucose, incubated at $36^{\circ} \mathrm{C}$ for 24 hours and transferred to tryptic soy broth (TSB) without dextrose (Difco), with $0.5 \%$ of sodium chloride, using the same glucose concentrations and incubation at $36^{\circ} \mathrm{C}$ for 24 hours. Thereafter, aliquots of the cultures were added to the TSB using the same glucose concentration until MacFarland scale 1 was obtained.

Later, $200 \mu \mathrm{L}$ of each bacterial suspension were inoculated, in triplicate, onto 96-well, flat-bottomed sterile polystyrene microtiter plates (Cral). Non-inoculated TSB wells, in triplicate, at each glucose concentration, were used as negative controls. The plates were incubated at $36^{\circ} \mathrm{C}$ for 24 hours. The bacterial suspension was aspirated and each well was washed three times with $250 \mu \mathrm{L}$ of sterile physiological saline at $0.9 \%$. After that, the biofilm was fixed with $200 \mu \mathrm{L}$ of methanol for 15 minutes, and later removed. The plates were dried at ambient temperature, stained with $200 \mu \mathrm{L}$ of Hucker's crystal violet solution at $2 \%$ for 5 minutes, washed in running water and dried at ambient temperature. Afterwards, absorbance was read using an ELISA plate reader (Rosys Anthos 2010) at $550 \mathrm{~nm}$.

The optical density $\left(\mathrm{OD}_{\mathrm{s}}\right)$ of each strain was obtained by the arithmetic mean of the absorbance of three wells and this value was compared with the mean absorbance of negative controls $\left(\mathrm{OD}_{\mathrm{nc}}\right)$. The following classification was used for the determination of biofilm formation: no biofilm production $\left(\mathrm{OD}_{\mathrm{s}} \leq \mathrm{OD}_{\mathrm{nc}}\right)$, weak biofilm production $\left(\mathrm{OD}_{\mathrm{nc}}<\mathrm{OD}_{\mathrm{s}} \leq 2 . \mathrm{OD}_{\mathrm{nc}}\right)$, moderate biofilm production $\left(2 . \mathrm{OD}_{\mathrm{nc}}<\mathrm{OD}_{\mathrm{s}} \leq 4 . \mathrm{OD}_{\mathrm{nc}}\right)$ and strong biofilm production $\left(4 . \mathrm{OD}_{\mathrm{nc}}<\mathrm{OD}_{\mathrm{s}}\right)$.

All Staphylococcus aureus strains analyzed produced biofilm on polystyrene at least at one of the concentrations used (Table 1).

Table 1. Results for biofilm production on microtiter plates for Staphylococcus aureus, Listeria and Escherichia coli in TSB at different glucose concentrations.

\begin{tabular}{lcccccccccccc}
\hline \multicolumn{1}{c}{ Tested media } & \multicolumn{3}{c}{$\begin{array}{c}\text { No biofilm } \\
\text { producers }\end{array}$} & \multicolumn{3}{c}{$\begin{array}{c}\text { Weak biofilm } \\
\text { producers }\end{array}$} & \multicolumn{2}{c}{$\begin{array}{c}\text { Moderate biofilm } \\
\text { producers }\end{array}$} & \multicolumn{2}{c}{$\begin{array}{c}\text { Strong biofilm } \\
\text { producers }\end{array}$} \\
\hline & S.a. & L. & E.c & S.a. & L. & E.c & S.a. & L. & E.c & S.a. & L. & E.c \\
\hline TSB w/o G & 4 & 1 & 0 & 8 & 3 & 3 & 0 & 3 & 4 & 0 & 0 & 3 \\
TSB + 0.5\% G & 11 & 4 & 0 & 1 & 1 & 2 & 0 & 2 & 8 & 0 & 0 & 0 \\
TSB + 1\% G & 11 & 1 & 1 & 1 & 5 & 2 & 0 & 1 & 7 & 0 & 0 & 0 \\
TSB + 1.5\% G & 1 & 3 & 0 & 11 & 4 & 7 & 0 & 0 & 3 & 0 & 0 & 0 \\
TSB + 2\% G & 3 & 2 & 0 & 7 & 1 & 3 & 1 & 4 & 7 & 1 & 0 & 0 \\
TSB + 2.5\% G & 5 & 0 & 0 & 7 & 3 & 2 & 0 & 4 & 8 & 0 & 0 & 0 \\
TSB + 3\% G & 8 & 1 & 0 & 3 & 4 & 5 & 0 & 2 & 5 & 1 & 0 & 0 \\
TSB + 3.5\% G & 8 & 0 & 2 & 1 & 2 & 1 & 0 & 4 & 6 & 3 & 1 & 1 \\
TSB + 4\% G & 2 & 0 & 4 & 4 & 3 & 0 & 1 & 4 & 5 & 5 & 0 & 1 \\
\hline
\end{tabular}

TSB: - Tryptic Soy Broth without dextrose - Difco; G: glucose.

S.a.: Staphylococcus aureus; L.: Listeria; E.c:Escherichia coli 
By using the polystyrene microtiter plate method, it was possible to find out that all strains of Listeria, Staphylococcus aureus and Escherichia coli had the capacity to produce biofilm, even if they are weak producers, in at least one of the growth media tested.

Although hygiene conditions for food production have been continuously improved in food industries, outbreaks of listeriosis caused by the consumption of contaminated products may occur, and therefore, providing an effective control of Listeria spp. has been a challenge (5). The strains of $L$. monocytogenes and L. welshimeri analyzed were obtained from stainless steel tables and from polyurethane conveyors, and showed weak and moderate biofilm formation in TSB with different glucose concentrations, but especially in media with 2 to $4 \%$ of glucose. An L. monocytogenes strain isolated from the polyurethane conveyor was a strong biofilm producer in TSB with $3.5 \%$ of glucose. These results were consistent with those obtained by Stepanovic et al. (12), who concluded that $L$. monocytogenes produces more biofilm in nutrient-rich media.

The data obtained in this study are very important because they show that Listeria, Staphylococcus aureus and Escherichia coli isolated from surfaces in contact with foods in the cutting room of a poultry slaughterhouse can produce biofilm, which may cause the persistence of these microorganisms during food processing and consequently lead to greater risks of food contamination, jeopardizing consumers' health. Further studies are still needed to determine on which surfaces and under which environmental conditions these microorganisms produce more biofilm.

\section{ACKNOWLEDGEMENTS}

We express our thanks to the Center for Food Research and to the Laboratory of Virology and Immunology of the School of Agronomics and Veterinary Medicine, Universidade de Passo Fundo, Brazil.

\section{REFERENCES}

1. Christensen, G.D.; Simpson, W.A.; Younger, J.J.; Baddour, L.M.;
Barrett, F.F.; Melton, D.M.; Beachey, E.H. (1985). Adherence of coagulase-negative staphylococci to plastic tissue culture plates: a quantitative model for the adherence of staphylococci to medical devices. J. Clin. Microbiol. 22, 996-1006.

2. Deighton, M.A.; Balkau, B. (1990). Adherence measured by microtiter assay as a virulence marker for Staphylococcus epidermidis infections. J. Clin. Microbiol. 28, 2442-2447.

3. Evancho, G.M.; Sveum, W.H.; Moberg, L.J.; Frank, J.F. (2001). Microbiological monitoring of the food processing environment. In: Downes, F.P.; Ito, K. (eds.) Compendium of methods for the microbiological examination of foods. 4 ed., American Public Health Association, Washington, p. 25-35.

4. Fitzpatrick, F.; Humphreys, H.; O'Gara, J.P. (2005). Evidence for ica ADBC-independent biofilm development mechanism in methicillinresistant Staphylococcus aureus clinical isolates. J. Clin. Microbiol. 43, 1973-1976.

5. Harvey, J.; Keenana, K.P.; Gilmoura, A. (2007). Assessing biofilm formation by Listeria monocytogenes strains. Food Microbiol. 24, 380392.

6. Hitchins, A.D. (2003) Detection and enumeration of Listeria monocytogenes in foods. In: BAM. Bacteriological Analytical Manual. http://www.cfsan.fda.gov/ ebam/bam-10.html.

7. Kornacki, J.L.; Johnson, J.L. (2001). Enterobacteriaceae, coliforms, and Escherichia coli as quality and safety indicators. In: Downes, F.P.; Ito, K. (eds.) Compendium of methods for the microbiological examination of foods. 4 ed., American Public Health Association, Washington, p. 69-82.

8. Lancette, G.A.; Bennett, R.W. (2001). Staphylococcus aureus and staphylococcal enterotoxins. In: Downes, F.P.; Ito, K. (eds.) Compendium of methods for the microbiological examination of foods. 4 ed., American Public Health Association, Washington, p. 387-403.

9. O'Gara, J.P. (2007). ica and beyond: biofilm mechanisms and regulation in Staphylococcus epidermidis and Staphylococcus aureus. FEMS Microbiol. Lett. 270, 179-188.

10. Rode, T.M.; Langsrud, S.; Holck, A.; Moretro, T. (2007). Different patterns of biofilm formation in Staphylococcus aureus under foodrelated stress conditions. Int. J. Food Microbiol. 116(3), 372-383.

11. Ryser, E.T.; Donnelly, C.W. (2001). Listeria. In: Downes, F.P.; Ito, K. (eds.) Compendium of methods for the microbiological examination of foods. 4 ed., American Public Health Association, Washington, p. 343356.

12. Stepanovic, S.; Irkovic, I.C.; Ranin, L.; Svabic'-Vlahovic, M. (2004). Biofilm formation by Salmonella spp. and Listeria monocytogenes on plastic surface. Lett. Appl. Microbiol. 38, 428-432.

13. Stepanovic, S.; Vukovic, D.; Dakic, I.; Savic, B.; Svabic-Vlahovic, M. (2000). A modified microtiter-plate test for quantification of staphylococcal biofilm formation. J. Microbiol. Methods 40, 175-179.

14. Stepanovic, S.; Vukovic, D.; Hola,V.; Bonaventura, G.; Djukic, S.; Irkovic, I.C.; Ruzicka, F. (2007). Quantification of biofilm in microtiter plates: overview of testing conditions and practical recommendations for 
Rodrigues, L.B. et al.

assessment of biofilm production by staphylococci. APMIS 71 (5), 687690

15. Swanson, K.M.J.; Petran, R.L.; Hanlin, J.H. Culture methods for
Biofilm production by Listeria, E. coli and S. aureus

enumeration of microorganisms. (2001) In: Downes, F.P.; Ito, K. (ed.) Compendium of methods for the microbiological examination of foods. 4 ed., American Public Health Association, Washington, p. 53-62. 